Ethos (Jurnal Penelitian dan Pengabdian Masyarakat): 269-278

\title{
Ibm Budidaya Dan Penanganan Pasca Panen Buah Jambu Biji Untuk Pasar SUPERMARKET
}

\author{
IBM CULTIVATION AND THE HANDLING OF GUAVA POST HARVEST FOR SUPERMARKET \\ SEGMENT
}

\author{
${ }^{1}$ R. Eviyati , ${ }^{2}$ Dodi Budirokhman \\ ${ }^{1,2}$ Fakultas Pertanian, Universitas Swadaya Gunung Jati Cirebon \\ email: ${ }^{1}$ hilari_ey2007@yahoo.com
}

\begin{abstract}
Pajambon village is a village center for the cultivation of guava in the district of Kuningan. The cultivation techniques and postharvest handling were not based on Standard Operating Procedure (SOP) and Good Handling Practices (GHP) such as the application of fertilizer was less precise, sanitary land that was not optimal, pest control was less precise, and postharvest handling were not done well. Yet the implementation of SOP and GHP in guava cultivation techniques lead to optimal production and quality of the crop of guava was low. Farmers' knowledge regarding guava cultivation techniques and post-harvest handling needs to be improved. The method was used in this program include counseling, training and monitoring (assistance). Results of these programs i.e. farmers understand the techniques of cultivation and postharvest handling in accordance with the SOP and $G H P$, the guava fruit yield increase qualified grade $A(\geq 250 \mathrm{~g})$, as well as the decrease in the yield of fruit guava qualified grade C (149 $\mathrm{g}-100 \mathrm{~g})$.
\end{abstract}

Key words: Cultivation, Guava fruit, Fruit quality, Postharvest

\begin{abstract}
Abstrak. Desa Pajambon adalah pusat budidaya buah jambu biji di kabupaten Kuningan. Teknik budidaya dan penanganan pasca panen disana tidak berdasarkan Standar Operasi Prosedur (SOP) dan penanganan pascapanen yang baik (Good Handling Practices/GHP) seperti penggunaan pupuk yang kurang tepat, kesuburan tanah yang tidak optimal, pengendalian hama yang tidak tepat, dan penanganan pascapanen yang tidak terlaksana dengan baik. Sekarang ini penerapan SOP dan GHP pada teknik budidaya buah jambu biji yang akan menyebabkan produksi dan kualitas hasil panen yang optimal ini sangatlah rendah. Pengetahuan petani mengenai teknik budidaya dan penanganan pascapanen harus ditingkatkan. Metode yang digunakan dalam program ini melingkungi konseling, pelatihan, dan pendampingan. Hasil dari program ini diantaranya adalah petani memahami teknik pembudidayaan dan penanganan pascapanen sesuai dengan SOP dan GHP, hasil panen dari buah jambu biji mengalami peningkatan kualitas menjadi $A(\geq 250 \mathrm{~g})$, serta penurunan hasil panen buah jambu biji yang berkualifikasi $C(149 \mathrm{~g}-100 \mathrm{~g})$.

Kata kunci: budidaya, buah jambu biji, kualitas buah, pascapanen
\end{abstract}

\section{Pendahuluan}

Secara umum kondisi penerapan teknik budidaya, teknik panen dan pasca panen buah jambu biji yang dilakukan oleh para petani anggota Kelompok Tani Hortikultura I maupun Kelompok Tani Hortikultura II belum sepenuhnya mengacu kepada cara budidaya buah jambu biji yang baik dan benar sesuai dengan Standar Operasional Procedure (SOP) dan Good Handling Practices (GHP). 
Penerapan teknik budidaya buah jambu biji oleh para petani masih bersifat tradisional dan tidak ramah lingkungan seperti, petani melakukan pemupukan tanpa didasarkan hasil analisis tanah, belum melakukan pemangkasan secara baik dan benar, tidak melakukan penjarangan dan pembrongsongan buah, tidak melakukan pengendalian hama dan penyakit secara terpadu, menggunakan pupuk kimia secara berlebihan dan belum memanfaatkan bahan organik sebagai pupuk di lahan pertanian, sehingga dengan teknik budidaya yang dilakukan petani, menyebabkan hasil panen yang diperoleh kedua Kelompok Tani tersebut tidak optimal baik terhadap jumlah produksi maupun produktivitasnya dan tidak sesuai dengan standar mutu/kualitas yang diinginkan pasar supermarket.

Selain dari kesalahan teknik budidaya, petani belum melakukan teknik panen yang baik dan benar. Kesalahan dalam kegiatan panen banyak terjadi terutama pada saat penentuan umur petik, pemetikan buah tidak menggunakan gunting, tidak melakukan proses penghilangan panas kebun (Cooling Down) terhadap buah jambu biji yang baru dipetik, serta kegiatan distribusi buah dari kebunke Gudang Pengemasan Kelompok Tani Hortikultura tanpa memerhatikan kapsitas dan jenis wadah sehingga menimbulkan gesekan fisik yang menimbulkan luka memar pada permukaan buah. Menurut Pantastico. ER. B (1973), gesekan permukaan buah dapat mengakibatkan melonjaknya respirasi. Setiyabudi dkk (2007) menambahkan, bahwa memar dan luka mekanis pada saat pemanenan akan tampak sebagai bercak berwarna coklat dan kehitaman selama dalam penyimpanan, serta luka-luka pada kulit buah akan menjadi pintu masuk bagi mikroba penyebab pembusukan.

Kualitas hasil panen akibat dari kegiatan budidaya yang dilakukan oleh petani yang tergabung dalam dua Kelompok Tani tersebut menyebabkan rata-rata ukuran buah jambu biji yang mempunyai bobot $\geq 250$ gr hanya mencapai $20 \%$ dari total hasil panen pada tahun 2015 sedangkan buah dengan bobot yang kecil yaitu antara 100 - 150 gr mencapai $40 \%$. Dilihat dari rata-rata tingkat kerusakan buah jambu biji akibat kesalahan dalam kegiatan budidaya, rata-rata tingkat kerusakan buah jambu biji mencapai 30\%. Sedangkan kerusakan/kehilangan hasil panen buah jambu biji (Causes of Losses) akibat dari kesalahan teknik panen (cara pemetikan) sebesar $30 \%$. Ditinjau dari mutu visual, pada umumnya mutu buah yang dihasilkan masih rendah, hal ini dapat dilihat dari banyaknya kulit buah yang tidak mulus, terdapat bercak coklat dan luka memar serta tingginya jumlah buah yang dipanen tanpa disertai tangkai buah.

Untuk meminimalisir permasalahan petani mitra baik di tingkat on farm maupun off farm, maka diperlukan adanya kegiatan pembinaan yang bertujuan meningkatkan pengetahuan dan keterampilan petani dalam hal budidaya dan penanganan pasca panen yang sesuai dengan SOP dan GHP, sehingga diharapkan baik produksi maupun mutu jambu biji yang dihasilkan dapat meningkat.

\section{Metode}

Metode yang dilakukan meliputi Penyuluhan, Pelatihan, Pendampingan (Monitoring). 


\section{Penyuluhan}

Penyuluhan dilakukan untuk mensosialisasikan kembali atau penyadaran terhadap salah satu pokok bahasan strategis yang berhubungan dengan permasalahan yang terjadi di Kelompok Tani Hortikultura I dan Kelompok Tani Hortikultura II. Teknik pelaksanaan penyuluhan dilakukan melalui pemaparan materi dari beberapa narasumber yang diteruskan dengan diskusi atau tanyajawab. Peserta penyuluhan adalah seluruh pengurus dan anggota dan tenaga kerja panen dan penanganan pasca panen Kelompok Tani Hortikultura I dan Kelompok Tani Hortikultura II. Sedangkan pembicara dalam kegiatan Penyuluhan adalah Tim Pengusul Program IbM,

\section{Pelatihan}

Pelatihan bertujuan untuk meningkatkan pengetahuan dan keterampilan kepada para petani anggota Kelompok Tani Hortikultura I dan Kelompok Tani Hortikultura II dan tenaga penanganan pasca panen di gudang pengemasan kedua Kelompok Tani tersebut sesuai dengan beberapapermasalahan yang teridentifikasi.

Teknik pelaksanaan pelatihan dilakukan melalui pemaparan materi dari beberapa narasumber yang diteruskan dengan praktek atau simulasi di lapangan dan diskusi. Peserta Pelatihan adalah seluruh pengurus dan anggota serta tenaga penanganan pasca panen Kelompok Tani Hortikultura I dan Kelompok Tani Hortikultura II. Sedangkan Pelatih dalam kegiatan ini adalah Tim Pengusul Program IbM.

\section{Pendampingan (Monitoring)}

Metode Pendampingan bertujuan untuk mengawal dan memonitoring implementasi/penerapan hasil dari pelatihan-pelatihan yang telah dilakukan sebelumnya. Sehingga kegiatan-kegiatan petani dapat meningkatkan kemampuan ilmu dan teknologi (up-datingipteks) para petani dan dapat peningkatan produktivitas di Kelompok Tani Hortikultura I dan Kelompok Tani Hortikultura II.

\section{Hasil dan Pembahasan}

Pelaksanaan kegiatan Pengabdian kepada Masyarakat "IbM Budidaya dan Penanganan Pasca Panen Jambu Biji untuk Pasar Supermarket" pada Kelompok Tani Hortikultura I dan Kelompok Tani Hortikultura II di Desa Pajambon Kecamatan Kramat Mulya sejak Bulan Mei sampai November 2015 telah dilaksanakan. Rangkaian kegiatan pengabdian yang dilakukan, meliputi: penyuluhan, pelatihan dan demontrasi tentang budidaya dan penanganan pasca panen jambu biji, serta pendampingan dan monitoring kegiatan Pengelolaan Kebun Percontohan. Pelaksanaan dan Pencapaian hasil kegiatan yang telah dilaksanakan secara rinci adalah sebagai berikut:

\subsection{Penyuluhan}

Kegiatan penyuluhan tentang Teknik Budidaya dan Penanganan Pasca Panen Jambu Biji dilaksanaan pada hari Rabu, 10 Juni 2015 Pukul 19.00 WIB yang berlokasi di Dusun Wage RT/RW 007/04 Desa Pajambon Kecamatan Kramat Mulya Kabupaten Kuningan. Metode penyuluhan dilakukan secara lisan dan tanya jawab. Pada saat pelaksanaan, penyuluhan diikuti oleh 30 orang peserta.

Kegiatan penyuluhan yang dilakukan oleh Tim IbM, secara tidak langsung telah menambah pengetahuan petani mengenai teknik budidaya, teknik panen serta 
penanganan pasca panen buah jambu biji yang baik sesuai dengan SOP (Standard Operational Procedure) dan GHP (Good Handling Practice)

\subsection{Pelatihan Pertama}

Pelatihan pertama mengenai aplikasi pupuk kandang, aplikasi Pupuk Organik Cair (POC), serta aplikasi pupuk anorganik (NPK) diselenggarakan di kebun percontohan pada hari Rabu, 13 Juni 2015 Pukul 09.00 WIB. Peserta pelatihan terdiri dari anggota Kelompok Tani Hortikultura I dan Kelompok Tani Hortikultura II. Kegiatan pelatihan dihadiri oleh 17 orang peserta. Kegiatan pelatihan ini merupakan langkah aplikatif dari penyuluhan pertama mengenai aplikasi pupuk yang tepat, efektif dan efisien. Pelaksanaan pelatihan dilakukan dengan metode demonstrasi dan diskusi.

\subsection{Pelatihan ke dua}

Pelatihan ke dua mengenai teknik pemangkasan dan perundukan tanaman diselenggarakan pada hari Minggu, 21 Juni 2015 Pukul 09.00 WIB di kebun percontohan. Peserta pelatihan terdiri dari anggota Kelompok Tani Hortikultura I dan Kelompok Tani Hortikultura II. Kegiatan pelatihan ke dua dihadiri oleh 21 orang peserta.Selama pelatihan, petani diberi pemahaman mengenai cara dan manfaat pemangkasan dan perundukan tanaman jambu biji yang baik dengan disertai demonstrasi (uji coba). Dalam kegiatan pelatihan ini, respon positif yang diperlihatkan oleh Mitra IbM tidak hanya dari segi jumlah peserta yang hadir, tetapi juga ditunjukan dengan cukup banyaknya pertanyaan yang diberikan seputar pemangkasan dan perundukan tanaman. Di samping itu, peserta juga berantusias untuk mempraktekan secara langsung cara pemangkasan dan perundukan yang baik pada saat kegiatan pelatihan.

\subsection{Pelatihan ke tiga}

Pelatihan ke tiga mengenai aplikasi herbisida dan pembrongsongan buah diselenggarakan di kebun percontohan pada hari Sabtu, 27 Juni 2015 Pukul 09.00 WIB dan dihadiri oleh 30 orang peserta. Sama halnya dengan pelatihan pertama dan pelatihan ke dua, peserta pelatihan terdiri dari anggota Kelompok Tani Hortikultura I dan Kelompok Tani Hortikultura II. Pelatihan dilakukan dengan metode demonstrasi dan diskusi. Selama kegiatan pelatihan berlangsung, peserta menunjukan respon yang baik dengan memperhatikan materi

IbM serta banyak memberikan pertanyaan mengenai pentingnya pembrongsongan buah dan dampak penggunaan herbisida yang berlebihan bagi lingkungan.

\subsection{Pelatihan ke empat}

Pelatihan ke empat merupakan pelatihan mengenai teknik panen buah jambu biji. Pelatihan dilaksanakan di kebun percontohan pada hari Minggu, 5 Juli 2015 Pukul 08.00 WIB - 09.30 WIB. Kegiatan ini dihadiri oleh 13 orang peserta. Peserta pelatihan merupakan anggota Kelompok Tani Hortikultura I dan Kelompok Tani Hortikultura II. Metode pelatihan yang digunakan adalah metode demonstrasi dan diskusi. Respon 
positif ditunjukan oleh peserta dari kebersediaan mereka mengikuti pelatihan hingga selesai disamping menyimak materi yang dipaparkan sekaligus demostrasi yang dilakukan oleh pemateri.

Selama pelatihan, peserta diberikan pembinaan mengenai teknik pemetikan buah yang benar dengan menggunakan gunting petik dan mengikutsertakan tangkai buah dengan panjang $\pm 3 \mathrm{~cm}$. Tujuannya adalah agar buah yang dipanen tidak mengalami luka fisik. Kriteria buah siap panen juga menjadi salah satu bahasan pada saat kegiatan pelatihan berlangsung. Buah yang siap panen dicirikan dengan warna hijau kekuningan dan kulit terlihat mengkilap. Setelah buah dipetik, selanjutnya Tim memberi pengarahan bahwa buah tidak boleh langsung dimasukan ke dalam keranjang panen, namun perlu diberi waktu untuk dapat melangsungkan proses penghilangan panas kebun (cooling down) dengan meletakan buah di bawah tajuk tanaman. Hal ini bertujuan agar kerusakan fisiologis dan kegiatan metabolisme buah selama penyimpanan dan pengiriman dapat ditekan sekecil mungkin sehingga mutu buah dapat dipertahankan.

\subsection{Pelatihan ke lima}

Pelatihan ke lima merupakan pelatihan mengenai teknik penanganan pasca panen buah jambu biji. Pelatihan dilaksanakan di Gudang Pasca Panen Kelompok Tani Hortikultura pada hari Minggu, 12 Juli 2015 Pukul 09.00 WIB - 11.00 WIB. Kegiatan ini dihadiri oleh 15 orang peserta. Peserta pelatihan merupakan anggota Kelompok Tani Hortikultura I dan Kelompok Tani Hortikultura II serta petugas yang menangani kegiatan pasca panen di gudang pasca panen Kelompok Tani Hortikultura.

Tim IbM memulai pelatihan dengan memberikan penjelasan terlebih dahulu kepada peserta mengenai pentingnya penanganan pasca panen yang benar bagi mutu produk buah jambu biji yang dihasilkan kemudian dilanjutkan dengan demontrasi tahapan pasca panen jambu biji sesuai GHP, seperti teknik sorting dan grading harus dilakukan secara ketat sehingga keseragaman mutu terjamin. Pada saat melakukan sorting dan grading, peserta diberi pemahaman untuk tidak menumpuk buah di atas lantai membentuk gunungan sehingga akan menyebabkan permukaan buah menjadi memar dan mengalami luka gesekan. Proses sorting dan grading juga harus dilakukan dengan hati-hati (tanpa dilempar) sehingga buah tidak memar, keriput, tidak cepat mengalami pembusukan, tekstur buah tidak lembek, serta rasa buah juga dapat dipertahankan.

Selain proses sorting dan grading, proses pengemasan juga penting diperhatikan. Pengemasan diperlukan dengan tujuan untuk mengurangi laju respirasi buah sehinga daya simpan dan mutu buah dapat dipertahankan. Tim IbM juga memberikan penjelasan bahwa dalam menyusun buah ke dalam peti kayu atau karton pengemasan harus memperhatikan kapasitas wadah sehingga kerusakan buah seperti tangkai potong, memar, luka gesek/lecet dapat diminimalisir.

\subsection{Pendampingan (Monitoring) Kegiatan Pengelolaan Kebun Percontohan}

Pendampingan (monitoring) pengelolaan kebun percontohan pertama dilaksanakan pada Hari Senin, 15 Juni 2015. Kegiatan yang dilakukan pada program pendampingan (monitoring) pertama merupakan upaya untuk mengetahui sejauh mana 
penerapan dari hasil pelatihan pertama mengenai aplikasi pupuk kandang, Pupuk Organik Cair (POC) dan pupuk anorganik (NPK). Pada saat monitoring, tim IbM melihat adanya petani mitra yang sedang mengaplikasikan pupuk kandang pada torakan yang telah dibuat mengelilingi pohon jambu biji. Namun demikian, cukup sulitnya medan yang ditempuh serta banyaknya jumlah pupuk organik yang dibutuhkan terkadang masih menimbulkan sedikit keluhan karena berkaitan dengan kemudahan pengangkutan dan efisiensi waktu kerja di lapangan.

Pendampingan (monitoring) kegiatan pengelolaan kebun percontohan ke dua dilaksanakan pada Hari Rabu, 24 Juni 2015. Kegiatan pendampingan ke dua terfokus pada kegiatan pemangkasan dan perundukan tanaman. Pada saat monitoring, terlihat adanya petani yang sedang melakukan pemangkasan baik terhadap cabang maupun melakukan pemangkasan hanya pada daun jambu biji. Perundukan tanaman sebagaimana yang telah dianjurkan pun sudah cukup banyak diterapkan oleh petani.

Pendampingan dan monitoring kegiatan pengelolaan kebun percontohan ke tiga dilaksanakan pada Hari Minggu, 28 Juni 2015. Kegiatan pendampingan ke tiga mengenai aplikasi herbisida dan pembrongsongan buah. Pada saat kegiatan pendampingan berlangsung, terlihat baik Mitra IbM I dan Mitra IbM II menerapkan anjuran untuk melakukan pembrongsongan buah jambu biji. Mereka melakukan pembrongsongan buah sesuai dengan yang telah diajarkan, yakni pembrongsongan dilakukan terhadap buah yang telah berumur 2 minggu setelah pembungaan (buah tidak lebih besar dari ukuran bola ping pong) serta melakukan pembrongsongan dengan memperhatikan posisi plastik yang tegak lurus (vertikal) ketika diikatkan pada tangkai tanaman. Di samping itu, beberapa petani juga terlihat sedang melakukan sanitasi lahan sehingga kebun menjadi lebih bersih.

Kegiatan monitoring dan pendampingan ke empat dilaksanakan pada Hari Minggu, 26 Juli 2015. Monitoring dan pendampingan dilakukan di kebun percontohan dan gudang pasca panen kelompok tani hortikultura. Kegiatan monitoring ke empat terfokus pada teknik panen dan penanganan pasca panen yang dilakukan oleh petani mitra, disamping memonitoring kegiatan budidaya. Pada saat kegiatan panen, terlihat beberapa petani melakukan teknik pemetikan sesuai dengan anjuran pada saat pelatihan. Petani memetik buah jambu biji menggunakan gunting petik dengan mengikutsertakan tangkai buah $\pm 3 \mathrm{~cm}$ dari pangkal buah, kemudian dilanjutkan dengan kegiatan penghilangan panas kebun (cooling down) dengan cara buah dikeringanginkan di bawah tajuk pohon. Pada saat kegiatan pendistribusian buah jambu biji dari kebun ke gudang pasca panen, petani sudah mulai memperhatikan kapasitas wadah pengangkutan sehingga resiko buah memar dan terkena luka gesek dapat diminimalisir.

Setelah kegiatan monitoring dan pendampingan di kebun mitra, monitoring dilanjutkan di gudang penanganan pasca panen Kelompok Tani Hortikultura. Pada saat kegiatan monitoring berlangsung, terlihat beberapa petugas pasca panen sedang melakukan sorting dan grading. Proses sorting dan grading dilakukan dengan hati-hati (tanpa dilempar). Proses pengemasan juga diterapkan dengan baik. Penyusunan buah di dalam peti kemas yang dilakukan oleh petani mitra sudah sesuai dengan kapasitas/volume peti. Penyusunan sudah dilakukan dengan penataan yang baik.

Kegiatan monitoring dan pendampingan selanjutnya dilaksanakan setiap 7 hari sekali selama bulan Agustus 2015 sampai dengan November 2015. Kegiatan monitoring dan pendampingan yang dilakukan oleh tim IbM meliputi teknik budidaya dan 
penanganan pasca panen buah jambu biji, seperti sanitasi kebun, perundukan tanaman jambu, pemangkasan pemeliharaan dan produksi, penjarangan dan pembrongsongan buah, teknik panen, pendistribusian buah dari kebun ke gudang pengemasan, penyortiran, pengkelasan, pengemasan serta penataan buah jambu segar ke dalam peti kayu sesuai dengan kapasitas wadah untuk pemasaran. Pada minggu pertama ditemukan beberapa kebun petani dengan kondisi kebersihan yang kurang terawat. Namun, setelah diadakan monitoring pendampingan lebih lanjut kesadaran petani akan pentingnya kebersihan kebun meningkat. Hal ini terlihat dari kondisi kebun mereka yang sudah bersih dari gulma. Selain dari aspek kebersihan atau sanitasi kebun, secara umum petani sudah menerapkan aspek penting dalam budidaya jambu biji lainnya seperti yang telah disebutkan diatas sesuai dengan SOP. Penanganan pasca panen juga dilakukan dengan baik dan sudah mengacu pada GHP.

Secara keseluruhan, capaian hasil program pengabdian masyarakat yang dilakukan oleh Tim IbM dapat dilihat pada tabel di bawah ini.

\section{Tabel 1. Kondisi Kelompok Tani Hortikultura Sebelum dan Sesudah Pembinaan}

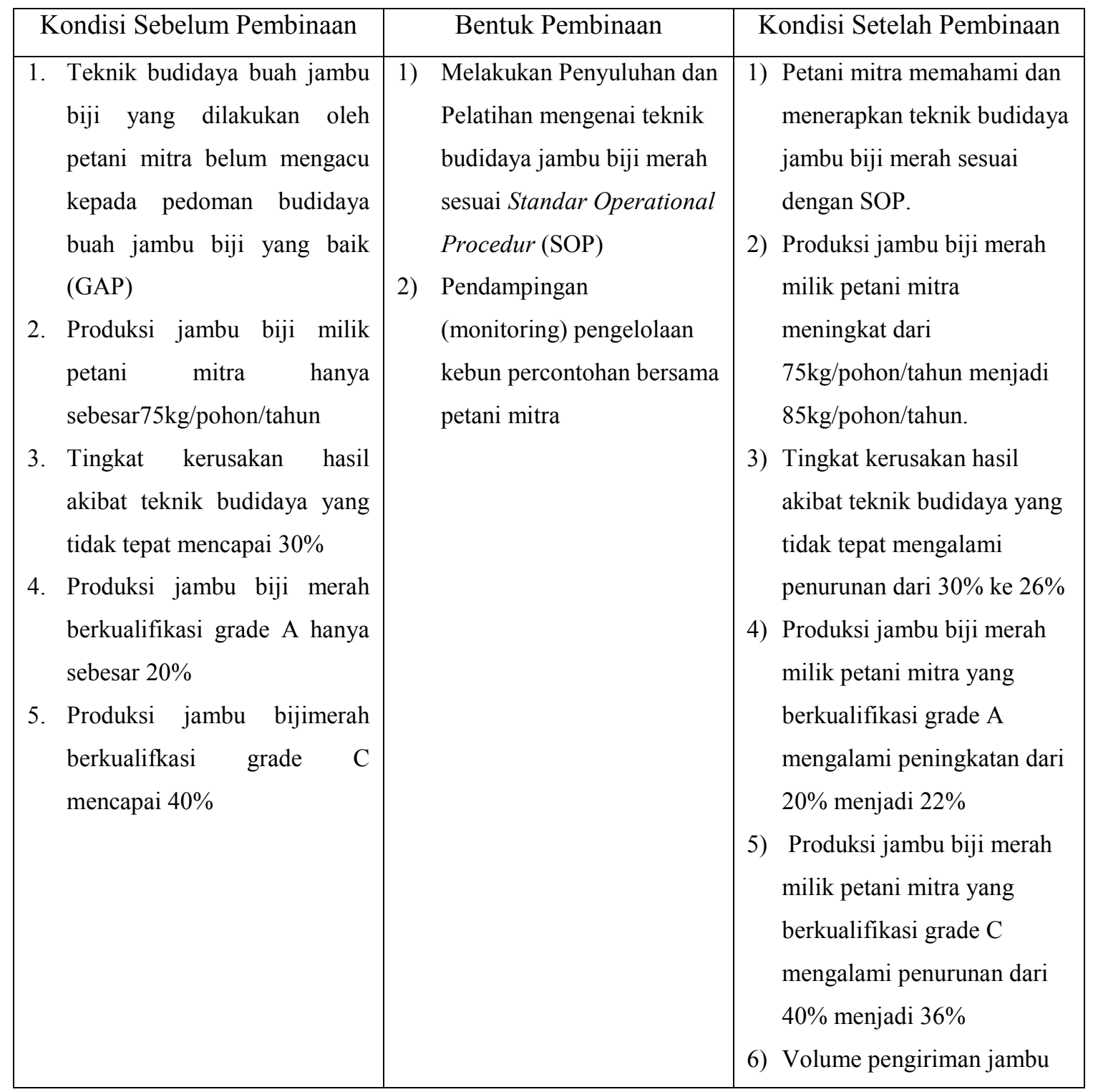




\begin{tabular}{|c|c|c|}
\hline & & $\begin{array}{l}\text { biji ke supermarket } \\
\text { meningkat }\end{array}$ \\
\hline $\begin{array}{l}\text { 1. Teknik Panen yang dilakukan } \\
\text { Penanganan Pasca Panen buah } \\
\text { jambu biji yang dilakukan } \\
\text { oleh petani mitra belum } \\
\text { mengacu kepada teknik } \\
\text { penanganan pasca panen buah } \\
\text { segar yang baik dan benar } \\
\text { sesuai dengan konsep Good } \\
\text { Handling Practice (GHP) } \\
\text { serta SOP panen dan } \\
\text { penanganan pasca panen } \\
\text { Jambu Biji. }\end{array}$ & $\begin{array}{l}\text { 1) Melakukan Pelatihan } \\
\text { mengenai teknik panen dan } \\
\text { penangan pasca panen } \\
\text { sesuai dengan Standar } \\
\text { Operational Procedur } \\
\text { (SOP) dan Good Handling } \\
\text { Practice (GHP) di kebun } \\
\text { mitra dan gudang } \\
\text { pengemasan }\end{array}$ & $\begin{array}{l}\text { 1) Petani mitra memahami dan } \\
\text { menerapkan teknik panen } \\
\text { dan penanganan pasca } \\
\text { panen jambu biji merah } \\
\text { sesuai dengan SOP dan } \\
\text { GHP. } \\
\text { 2) Tingkat kerusakan hasil } \\
\text { akibat kesalahan teknik } \\
\text { panen mengalami } \\
\text { penurunan dari } 30 \% \\
\text { menjadi } 25 \%\end{array}$ \\
\hline
\end{tabular}

Tabel 2. Tingkat Kerusakan Hasil Akibat Kesalahan Teknik Budidaya Sebelum dan Sesudah Program IbM

\begin{tabular}{|c|r|r|r|r|r|}
\hline \multirow{2}{*}{ Kondisi } & \multicolumn{3}{|c|}{ Tingkat Kerusakan Buah Akibat Kesalahan Teknik Budidaya (\%) } & $\begin{array}{c}\text { Jumlah } \\
\text { Tingkat } \\
\text { Kerusakan } \\
\text { Hasil }\end{array}$ \\
\cline { 2 - 5 } & Buah Gosong & Serangan Ulat & $\begin{array}{c}\text { Gesekan } \\
\text { Daun }\end{array}$ & Lalat Buah & 30,33 \\
\hline \hline $\left.\mathrm{A}^{*}\right)$ & 8,67 & 7,17 & 9,33 & 5,17 & 26,83 \\
\hline $\left.\mathrm{B}^{*}\right)$ & 7,83 & 6,50 & 7,83 & 4,67 & \\
\hline \multicolumn{6}{c}{ Keterangan } \\
\hline \multicolumn{4}{c|}{ A: Sebelum Program IbM ; B: Setelah Program IbM } \\
\hline
\end{tabular}


Tabel 3. Tingkat Kerusakan Hasil Akibat Kesalahan Teknik Panen Sebelum dan Sesudah Program IbM

\begin{tabular}{|c|r|r|r|r|}
\hline \multirow{2}{*}{ Kondisi } & \multicolumn{2}{|c|}{$\begin{array}{c}\text { Tingkat Kerusakan Mekanis Akibat Kesalahan Teknik } \\
\text { Panen (\%) }\end{array}$} & $\begin{array}{c}\text { Jumlah Tingkat } \\
\text { Kerusakan Hasil }\end{array}$ \\
\cline { 2 - 5 } & Tidak Bertangkai & Luka Memar & Luka Gesekan & \\
\hline \hline $\left.\mathrm{A}^{*}\right)$ & 10,83 & 10,67 & 8,67 & 25,33 \\
\hline $\left.\mathrm{B}^{*}\right)$ & 8,33 & 9,17 & 7,83 & \\
\hline \multicolumn{4}{|c|}{$\begin{array}{c}\text { Keterangan } \\
\end{array}$} \\
\hline \multicolumn{4}{|c|}{ A: Sebelum Program IbM ; B: Setelah Program IbM } \\
\hline
\end{tabular}

Tabel 4. Persentase Grade/Ukuran Jambu Biji Sebelum dan Sesudah Program IbM

\begin{tabular}{|c|c|c|c|}
\hline \multirow[b]{2}{*}{ Kondisi } & \multicolumn{3}{|c|}{ Grade/Ukuran Jambu (\%) } \\
\hline & $\begin{array}{c}\geq 250 \mathrm{~g} \\
\text { (Grade A) }\end{array}$ & $\begin{array}{c}249 \mathrm{~g}-149 \mathrm{~g} \\
\text { (Grade B) }\end{array}$ & $\begin{array}{c}150 \mathrm{~g}-100 \mathrm{~g} \\
(\text { Grade C) }\end{array}$ \\
\hline $\left.\mathrm{A}^{*}\right)$ & 20,17 & 39,17 & 40,67 \\
\hline $\left.\mathrm{B}^{*}\right)$ & 22,00 & 41,33 & 36,67 \\
\hline
\end{tabular}

Berdasarkan tabel di atas, dapat dikatakan bahwa pengetahuan dan keterampilan petani mengenai teknik budidaya dan penanganan pasca panen semakin meningkat. Adopsi IPTEKS ini disertai dengan penerapan di lapangan sehingga baik produksi maupun mutu buah yang dihasilkan mengalami peningkatan.

Produksi buah mengalami peningkatan sebesar 12,8\% dari angka sebelumnya. Menurut Wartapa dkk. (2009), pemangkasan merupakan usaha untuk memperbaiki kondisi lingkungan seperti suhu, kelembaban, dan cahaya sehingga akitivitas fotosintesis berlangsung dengan baik. Sumarni (1996)dalam Meliawati (2014) menambahkan bahwa pemangkasan dapat meningkatkan $\mathrm{C} / \mathrm{N}$ rasio sehingga terjadi penumpukan karbohidrat yang dapat membentuk tunas-tunas produktif untuk menghasilkan bunga dan buah.Dengan demikian produksi buah jambu biji meningkat.

Pada tabel 2, terlihat tingkat kerusakan hasil akibat teknik budidaya yang salah mengalami penurunan dari $30,33 \%$ menjadi $26,83 \%$.Hal ini sejalan dengan pernyataan Noorbaiti dkk. (2015) yang menyatakan bahwa untuk menghambat atau meminimalisir kerusakan buah, maka saat buah masih di pohon perlu dilakukan pembrongsongan, sehingga selama proses perkembangan dan pematangan buah, hama yang menyerang buah jambu biji dapat diminimalisir. Selain itu, buah dapat terhindar dari gesekan daun maupun buah lain di sekitarnya yang dapat menimbulkan luka fisik sehingga menurunkan mutu buah.

Persentase buah jambu biji berkualifikasi grade A $(\geq 250 \mathrm{~g})$ mengalami peningkatan dari angka $20 \%$ menjadi $22 \%$. Sementara persentase buah jambu biji 
berkualifikasi grade C (150 g - $100 \mathrm{~g})$ mengalami penurunan dari angka 40\% menjadi $36 \%$. Adanya penjarangan buah yang dilakukan petani, menyebabkan fotosintat terakumulasi dalam buah tanpa harus mengalami persaingan dengan buah yang lain,sehingga ukuran dan bobot buah meningkat (Wartapa dkk., 2009).

\section{Kesimpulan}

Dari hasil kegiatan pengabdian yang telah dilaksanakan, maka dapat ditarik kesimpulan:

1. Transfer IPTEKS mengenai teknik budidaya dan penanganan pasca panen jambu biji yang diberikan pada saat penyuluhan dan pelatih, secara umum telah diterapkan oleh kedua Mitra IbM dalam mengelola Kebun Percontohan.

2. Produksi jambu biji mitra meningkat dari $75 \mathrm{~kg} /$ pohon/tahun menjadi 85 $\mathrm{kg} /$ pohon/tahun.

3. Persentase kerusakan hasil akibat kesalahan teknik budidaya menurun dari $30 \%$ menjadi $26 \%$.

4. Persentase kerusakan hasil akibat kesalahan teknik panen menurun dari $30 \%$ menjadi 25\%.

5. Buah jambu biji berkualifikasi grade A mengalami peningkatan dari $20 \%$ menjadi 22\%. Sedangkan buah jambu berkualifikasi grade $\mathrm{C}$ mengalami penurunan dari $40 \%$ menjadi $36 \%$.

\section{Daftar pustaka}

Meliawati, N. C. 2014. Respon pemberian jenis mulsa plastic dan pangkas pucuk (toping) terhadap pertumbuhan dan kualitas tanaman melon (Cucumis melo L.) Varietas Apollo. Skripsi. Jurusan Agroteknologi. Fakultas Pertanian Universitas Sultan Ageng Tirtayasa.

Pantastico. ER. B. 1973. Penyimpanan secara komersial. Fisiologi Lepas Panen. Gajah Mada University Press. Yogyakarta

Setyabudi, D. A., Wisnu Broto, Setyadjit, Ridwan Rahmat, Rokhani Hasbullah, Sulusi Prabawat, Kun Tant Dewandari, dan Ira Mulyawant. 2007. Penelitan dan PengembanganTeknologi Pascapanen Jambu Biji Untuk Pemasaran Lokal dan Ekspor. Laporan Akhir Tahun. Balai Besar Penelitan dan Pengembangan Pascapanen Pertanian

Wartapa, I., Y. Effendi, Sukadi. 2009. Pengaturan jumlah cabang utama dan penjarangan buah terhadap hasil dan mutu benih tomat Varietas Kaliurang (Lycopersicum esculentum Mill). Jurnal Ilmu-ilmu Pertanian. Vol 5 (2) : 150-163

Noorbaiti, I., S. Trisnowati, S. Mitrowiharjo. 2015. Pengaruh warna plastik dan waktu pembrongsongan terhadap mutu buah jambu biji (Psidium guajava L.)http://download.portalgaruda.org/article.php?article=2596\&val=291. Diakses tanggal 14 Desember 2015 